\title{
Bedensel Sorunlar Çerçevesinde Karşılaştırmalı Bir İnceleme: Dokuzuncu Hariciye Koğuşu ve İnsanın Esareti (Of Human Bondage)
}

\author{
ARŞ. GÖR. FATOŞ IŞIL BRITTEN*
}

Öz

Fiziksel rahatsızlıklar, bedensel kusurlar gibi bedene dair sorunlar dünya edebiyatında sıklıkla karşımıza çıkan konulardır. Edebiyatın bu tip sorunlar yaşayan kurgusal karakterler üzerinden duygudaşlık geliştiren katartik bir gücü olduğu yadsınamaz. Özellikle psikolojik tahliller açısından zengin bir edebî metin, hem bedensel sorunların bireylerin kişiliklerini nasıl etkilediğini hem de kişilerin içinde bulundukları duygu durumlarını anlamamıza yardım eder. Bu noktada Türk edebiyatının sayılı romanlarından biri olan Peyami Safa'nın Dokuzuncu Hariciye Koğuşu (1930) ve İngiliz edebiyatının beğenilen romanlarından W. Somerset Maugham'ın İnsanın Esareti (Of Human Bondage) (1915) bedensel sorunları ve bunların yol açtığı doğrudan ve dolaylı ruhsal acıları başkahramanların iç dünyaları aracılığıyla ele alır. Dokuzuncu Hariciye Koğuşu'nun isimsiz genci dizinde oluşan kemik vereminden dolayı giderek artan bir şekilde yürüme güçlüğü çekmekte ve bacağının kesilmesi endişesini taşımaktadır. İnsanın Esareti'nin ana karakteri Philip Carey ise doğumsal bir deformasyon olan yumru ayak sorunu ile baş etmeye çalışır ve o da yürüme güçlüğü çekmektedir. Bu noktada bu romanlar oluşum romanı (Bildungsroman) olmaları yani çocukluktan olgunluk dönemine geçişi anlatmaları bakımından dikkat çekicidir, çünkü bu edebî alt tür sayesinde okuyucu genç yaşlarda bahsedilen başkahramanların kişiliklerinin nasıl oluştuğunu gözlemleme fırsatı yakalar. Bu tür detaylar bedensel sorunların psikolojik yansımalarını ortaya çıkarmak açısından bu romanlara yardımcı olur. Bu çalışmada Peyami Safa'nın Dokuzuncu Hariciye Koğuşu ve W. Somerset Maugham'ın İnsanın Esareti (Of Human Bondage) romanları karşılaştırmalı edebiyat disiplini çerçevesinde incelenecek olup romanlar arasındaki paralellikler görünür kılınacaktır.

Anahtar Sözcükler: Karşılaştırmalı edebiyat, Dokuzuncu Hariciye Koğuşu, İnsanın Esareti, bedensel sorunlar, oluşum romanı

\section{BODILY PROBLEMS: A COMPARATIVE LITERARY ANALYSIS OF DOKUZUNCU HARİCIYE KOĞUŞU AND OF HUMAN BONDAGE}

\section{Abstract}

Bodily problems such as physical disorders or defects are the themes one often encounters in world literature. Literature, surely, has the cathartic power to develop empathy through fictional characters with such problems. A particularly rich literary text, in terms of psychological analysis,

* Trakya Üniversitesi, isilcihan1@yahoo.com, orcid: 0000-0001-6020-2227

Gönderilme Tarihi: 24 Ocak $2021 \quad$ Kabul Tarihi: 18 Mart 2021 
allows us to understand how bodily problems affect the personalities of individuals as well as their general moods. Herein, Peyami Safa's Dokuzuncu Hariciye Koğuşu (1930), a prominent novel in Turkish literature and W. Somerset Maugham'in Insanın Esareti (Of Human Bondage) (1915), a much admired novel in English literature, both address bodily issues and the direct or indirect psychological sufferings that they cause through revealing the inner lives of their protagonists. The anonymous hero of Dokuzuncu Hariciye Koğuşu has increasing difficulty walking due to bone tuberculosis on his knee and worries about amputation. Philip Carey, the protagonist of Of Human Bondage, copes with a club foot which is the result of a birth deformity and, therefore, has a similar difficulty walking. At this point, it is notable that both novels are Bildungsroman, a narrative about the transition years from childhood to adulthood, because thanks to this sub-genre the reader has the opportunity to observe the formation of the aforementioned protagonists' personality. Such details in these novels help to unveil and unpack the psychological outcomes of bodily problems. This paper intends to scrutinize Peyami Safa's Dokuzuncu Hariciye Koğuşu and W. Somerset Maugham's Of Human Bondage within the frame of comparative literature and make the parallelisms between these Works more visible.

Keywords: Comparative literature, Dokuzuncu Hariciye Koğuşu, Of Human Bondage, bodily problems, Bildungsroman

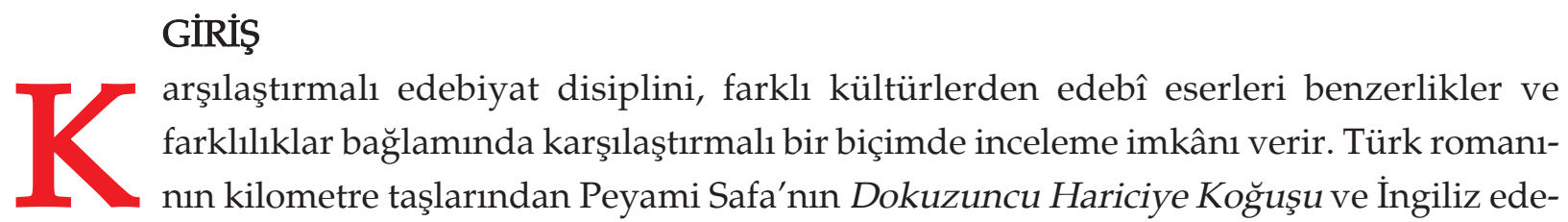
biyatının en bilinen romanlarından biri olan W. Somerset Maugham'ın Insanın Esareti (Of Human Bondage) adlı eseri bedensel sorunların psikolojik yansımaları çerçevesinde önemli koşutluklar gösterir.

Shakespeare'in kambur ve şeytani III. Richard'1 veya Herman Melville'in intikam takıntılı kötürüm karakteri Kaptan Ahap gibi birçok ünlü kurgu karakterden de anlaşılacağı üzere klasik Batı edebiyatında bedensel kusur ve engellilik çoğu zaman karakter bozukluğu hatta kötülük ile özleştirilmiştir. (Margolis vd. 1987,s. 18-19). Benzer şekilde Susan Sonntag veba, verem ya da kanser gibi hastalıkların uzun yıllar boyunca toplumları dehşete düşürdüğünü bu nedenle hastalık sahiplerinin sağlıklı insanlar tarafından damgalandığını ve toplumdan tecrit edilmeye çalışıldıklarını belirtir. (1978). Bu durum bedensel sorunlardan muzdarip kişileri var olan sağlık sorunlarının yanı sıra içinde bulundukları toplumun ön yargıları, dışlama ve damgalamaları ile mücadele etmek zorunda bırakır. Klasik Batı edebiyatındaki sayısız kötü örneğe karşın birçok edebiyat eseri ise bedensel sorunları olan kahramanlar üzerinden toplumun bedensel kusura veya rahatsızlığa bakış açısını değiştirme gücüne sahiptir. Hem Dokuzuncu Hariciye Koğuşu hem de İnsanın Esareti (Of Human Bondage) romanları çocukluklarından itibaren bedensel sorunlar yaşayan başkahramanları vasıtasıyla bu bedensel sorunları daha görünür kılar ve bu karakterlerin iç dünyalarını anlamamıza olanak sağlar.

\section{PEYAMI SAFA VE DOKUZUNCU HARICIIYE KOĞUŞU}

Dokuzuncu Hariciye Koğuşu (1930) Peyami Safa'nın diğer eserlerine göre daha az çalışılmış bir romandır. Ayrıca Orta Doğulu ve Batılı kültürlerin ikili bir karşıtlık olarak değerlendirildiği ve Fredric Jameson'un ulusal alegori olarak sınıflandırdığı romanlara örnek olarak gösterebileceğimiz çoğu eserlerinden ideolojik bakış açısının biraz daha arka planda kalması ile ayrışır (Gürbilek, 2010, s. 175). "Doğunun, Doğu gibi kalmaması, değişmesi, ama Batıyı da olduğu gibi almaması gerektiğini" 
savunan Safa Dokuzuncu Hariciye Koğuşu romanında Doğu-Batı sorunsalından ziyade hastalık kavramı ve bireyin iç dünyasını odak noktası olarak alır. Kurgusal dış dünyada olup bitenler korku, üzüntü, keder, utanç gibi içeride yaşanan yoğun duygular ile harmanlanır (Arpa, 2017, s. 141).

$\mathrm{Bu}$ kısa romanda anlatıcı ile roman kahramanı aynı kişidir. ${ }^{1}$ Anlatıcı hastane ortamını aşırı duygusallığa vardırmadan betimler ancak okuyucunun romanın atmosferindeki ince hüznü fark etmemesi olanaksızdır. Sağlıklı insandan beklenen güçlü, ritmik veya hızlı ayak seslerinin yerini bir hastanın muşambalara sürtünen ayak sesi alır, bir umut olarak görülen doktor ise sağlıklı bedeni ile hastalara tezat oluşturur. $\mathrm{O}$, hastanın elini uzattığında kaybolabilecek bir hayal gibi "köpüklenerek uçan ve uzaklara kaybolan beyaz gömleği" ile hızlıca hareket edebilmektedir ve anlatıcı hastane koridorlarını gerçek dünyayı iç dünyasının süzgecinden geçirerek, neredeyse izlenimci bir ressam gibi resmeder (DHK, s. 7). ${ }^{2}$

Hâlâ çocuk olan ana karakter "yalnız bende meçhul bir hastalık vardı, sekiz yaşımdan beri çekiyordum" derken aslında "ancak benim bir hastalığım vardı" demenin yanında kendisinin aynı zamanda çok yalnız olduğunu da belirterek bir sözcük oyunu yapar. (DHK, s. 9) Bu yalnızlık hem hastanede ona eşlik eden bir yetişkinin olmayışından hem de sağlıklı varlıkların dünyasında hastalığı ile diğer canlılardan ayrıldığını düşünmesinden kaynaklanır; "Ağaçların bile sıhhatine imrendiğini" birçok kez vurgulaması, belirsiz hastalığı ile sağlıklı kişilerin dünyasına dâhil olamamanın neden olduğu ıstırabı işaret eder ve ana rahmine dönmek istercesine bir köşeye ilişip büzülerek ebeveyn rolü atfettiği doktoru bekler (DHK, s. 9).

Anlatıcı, hastalık ibaresi gösteren her şeye sempati duyma eğilimindedir. Nesnelerde bile sağlam ve dayanıklı olan yerine kendisi gibi hastalıklı, kırılgan, hassas olanı yeğler. Örneğin, annesi ile birlikte yaşadıkları kenar mahalledeki evleri hasta insanlar gibi tasvir eder:

[...] Birbirine ufunetli adaleler gibi geçmiş, yaslanmış tahta evler. Her yağmurda her küçük fırtınada sancılanan ve biraz daha eğilip büğrülen bu evlerin önünden her geçişimde, çoğunun ayrı ayrı maceralarını takip ederdim. Kiminin kaplamaları biraz daha kararmıştır, kiminin şahnişini biraz daha yumrulmuştur, kimi biraz öne eğilmiş, kimi biraz çömelmiştir; ve hepsi hastadır, onları seviyorum; çünkü onlarda kendimi buluyorum; ve hepsi iki üç senede bir ameliyat olmadıkça yaşayamazlar, onları çok seviyorum; hepsi, rüzgârdan sancılandıkça ne kadar inilderler ve içlerinde ne aziz şeyler saklarlar, onları çok... çok seviyorum. (DHK, s. 16)

Kahraman hasta olan bu evlerin içlerinde çok değerli şeyler barındırdıklarını belirtir ve kendisinin dış görünüşüne zıt olarak iç dünyasının oldukça zengin olduğunu ima eder. Hastalık romanın o kadar merkezindedir ki roman kahramanı onu kişileştirmeden anlatamaz. Yarası iyileşmek için "iki obur dudak gibi gaz bezini emer" ve hava ile temas ettikçe çıplak etin derisi bir roman karakteriymişçesine anlatıcıdan daha çok ürperip korkar (DHK, s. 10-11). Bacağındaki yaralı eti onu sağlıklı bireylerden ayıran bir düşman gibi görmektense bu uzvu yoğun yalnızlık duyguları içinde onun duygularını paylaşan bir yoldaş gibi görür. Ameliyat öncesi bacağını kaybetme riski ile karşı karşıyayken hasta uzvuna bakıp ona acır:" Celladın bıçağına teslim olacak olduktan sonra senelerce bu acıyı niçin" çekip kan ağlamıştır? (DHK, s. 91). Bu acıma temelde kendine acıma duygusudur. Yaralı bacak diğer sağlıklı uzuvların içerisinde ayrıksıdır, mücadelecidir, çilekeştir. "İdama mahkûm bir kardeş gibidir" (ibid). Yalnızlı̆̆ının ortasında onunla aynı dertlerden muzdarip, sahip olamadığı kardeşidir. Aslında bacağının kısaltılması anlatıcının sağlığı için gereklidir ancak bu uzvun yokluğunu hayal bile edememesinin sebebi kendi yokluğunu tahayyül etmek istemeyişindendir çünkü hasta bacağı ile kendini özdeşleştirmektedir. Tartışmasız, bu uzuv kimliğinin önemli bir parçasıdır.

Beşir Ayvazoğlu, Peyami adlı biyografisinde Safa'nın 1908 yılında başlayan hastalığı sebebiyle

\footnotetext{
${ }^{1}$ Roman kahramanının bir ismi yoktur. Bu çalışmada kendisinden çocuk, roman anlatıcısı veya kahramanı olarak bahsedilecektir.

${ }^{2}$ Dokuzuncu Hariciye Koğuşu isimli romandan yapılacak alıntılarda romanın adı "DHK" şeklinde verilecektir.
} 
"kendini birden doktorların, hastabakıcıların, ilaç kokularının, psikoloji ve tıp kitaplarının ortasında bulduğunu belirtir (2017, s. 57). Safa gibi anlatıcı kahraman da sıklıkla hastane ortaminda bulunur ve doktorlar ile oldukça yakın bir ilişkisi vardır. Uzun süreden beri hastaneye gidiyor oluşu, yaşından büyük, ciddi mizacı ve yüksek kavrayış kapasitesi sayesinde hastanın doktorlarla oldukça arkadaşça bir ilişkisi vardır. Doktoru ile yemeğe çıkar, hasta iken doktoru onu evinden alır. Hastane aslında bir nevi okul görevi görmektedir. Anlatıcının iyi düzeydeki Fransızcasının da yardımıyla yaklaşık on yılda birçok cerrahi terim öğrenmiştir. Ameliyathaneleri, laboratuvarları gezmiştir. Hamlet'e göndermeler yapılan "Zavallı Yorik" aldı bölümde doktoru onu teşrihhaneye götürüp adeta bir tıp öğrencisine ders verir gibi bu öğrenme merakı fazla olan hastaya konuyla ilgili bilgiler verir, sonrasında da onu otopsi dersine sokar. Ancak edebiyata belirgin bir merakı olan hassas ruhlu kahraman için teknik bilgilerden ziyade otopsi odasında gördüğü cesetler dolayısıyla ölüm mefhumu ilgisini çeker ve Hamlet'in mezarlık sahnesini yoğun bir şekilde hatırlar. Otopsi masasının üzerinde gördüğü ölüye uygulanan ampütasyon ameliyatı kendisinin olmaktan kaçındığı ameliyattır. Hastalığı nedeniyle o, doktorların dünyasından ziyade cesetlerin âlemine daha yakındır. Hamlet'in uşağ1 Horatio ile konuşmasını zihninde canlandıran anlatıcı, Hamlet'in saray soytarısı Yorik'in kafatasını eline alıp ölüm ile ilgili duygu ve düşüncelerini aklından geçirir. Üstelik Yorik'in ölü olması ironiktir. O soytarıların bile "en neş'elisi"dir (DHK, s. 38). Şarkıları, şakaları ve kahkahalarıyla ölüme en uzak görünen kişinin bile gelip geçici mevcudiyeti hasta ve yalnız bir çocuk olan anlatıcıya ölülerle çevrili bir odada kendinin ölüme ne kadar yakın olduğunu fark ettirir. Zavallı Yorik nidası aslında zavallı kendim diyen bir feryattır.

Gerçekçilik akımının bir adım ötesi diyebileceğimiz, sanatta pozitif bilimleri ele alan natüralizm akımının etkilerini özellikle "Zavallı Yorik" ve "İlk Lokma" gibi teşrihhane ile ilgili bölümlerde görmekteyiz. Otopsi dersinin akabinde gittikleri lokantada doktoru kahramanı sağlık gerekçesiyle et yemesi için zorlar. Doktor ile hasta, sanat/entelektüellik ile pratiklik dikotomisinde iki farklı uçta durmaktadırlar, bu nedenle doktor hastanın iç dünyasını tam olarak kavrayamaz. Et yemeği anlatıcıya biraz önce görmüş olduğu kadavraları hatırlatır ve damağında çürümüş insan eti, genzinde de morgun ağır kokusunu hisseder, "ölülerden birinin yanağını ısırmış gibi"dir (DHK, s. 41). Doktor için kadavralarla çalışmak günlük, olağan bir durumken ameliyat olmaktan korkan hasta ve hassas bir çocuk için ölümün yalın hali ile yüzleşmek travmatiktir.

Ancak kahramanı gerçekten sarsan ve hastalığının giderek şiddetlenmesine neden olan şey uzak akrabası, kendinden dört yaş büyük Nüzhet'e umutsuz bir aşkla bağlanmasıdır. Nüzhet, Erenköy’de bir köşkte tasasız büyümüş, ayrıcalıklı bir sınıftan gelen bir paşa kızıdır. İlişkilerinin anlatıldığı ilk bölümler yaşama sevinci, iyimserlik ve iyiye giden sağlık ile şekillense de son bölümler, ilişkinin bozulması, Nüzhet'in damat adayı doktor Ragıp ile evlenmeye karar vermesi ile yoğunlaşan ıstırap, melankoli ve bu duyguların neden olduğu, engelliliğe yol açabilecek kadar ağır seyretmeye başlayan hastalık ile biçimlenir. Nüzhet bedenen oldukça sağlıklı, neşeli, çocuksu, alaycı, kimi zaman içten pazarlıklı ve derin duyguları olmayan bir karakter olarak çizilmiştir. Bu anlamda roman kahramanının çoğu açıdan tam tersidir ve bu zıtlık kahramanın Nüzhet'i arzulamasının muhtemel sebebidir. Hatta acı çekmeye alışmış, kendisini ancak kendine acımak yoluyla sevebilen kahramanın sevgili olarak ulaşılmaz birini seçmesinin rastlantı olmadığı da ileri sürülebilir.

Roman kahramanının hassas karakter yapısının sebebi hastalığının getirdiği zorluklar olsa da kahramanın aile yapısı da melankolik ruh halini perçinler. Çocuk bir yetimdir ve ne kadar iyi niyetli olursa olsun zayıf ve oğluna destek olamayan silik bir annesi vardır. Anne, hastane ortamında oğlunun yanında değildir ve ona yeterince destek olamaz. Kahraman annesini üzmemek adına çocuk haliyle hastalığının şiddetini annesinden gizler. Bu nedenle aralarındaki ebeveyn-çocuk ilişkisindeki 
roller yer değiştirmiştir diyebiliriz. Üstelik anlatıcı onu koruyacak bir babadan da mahrumdur. Annesi evde acılarına ağlamaktadır. Dolayısıyla anlatıcı "[k]endisine zaafından ziyade metanetini gösterdiği" iyi niyetli fakat zor durumunda ona destek olamayan zayıf karakterli annesi, fakirliği ve en çok da onu sakatlığa götürebilecek ağır hastalığı nedeniyle kendini yetersiz hissetmektedir (DHK, s.17). En masumane şakada bile kendinden şüphe edecek kadar aşağılık hissiyatı geliştirmiştir: "Ben Nüzhet'in kahkahalarından ürkerim, bu bir silahtır ki Nüzhet onu başkalarının zaafları üzerine merhametsizce boşaltır [...] ve nadir olarak da açtığı yaraya acır" (DHK, s. 26). Kahraman oldukça alıngan olduğu için olası bir eleştiriye maruz kalmaktan korkar ve ruhsal bir yara almamak için içine kapanır. Anlatıcının hissettiği aşağılık duygusu ve diğer insanların onun hakkındaki düşünceleri ile ilgili hassaslığı ne yazık ki yersiz değildir. Anlatıcı, Nüzhet ve annesi arasında geçen aşağıdaki talihsiz diyaloğa kulak misafiri olur:

-İşit! İşitmelisin! Canını sokakta mı buldun? Maazallah Mikrop. [...] Sonra... çekersin (Ses artıyor). Anladın mı? Çekersin!

-(Şiddetli) Anne! Ben vallahi (Ses azalıyor) değil... (Ses artıyor) vallahi yaklaşmıyorum, vallahi uzak duruyorum.

-Şakası yoktur kızım, mikrop bu...

- [...] Ayırttım... Çatalına kaşı̆̆ına işaret...(Yüksek sesle) Evin her tarafı mikrop... (DHK, s. 69-70).

Kahraman baştan beri özellikle yengesi tarafından hastalığı sebebiyle dışlanmakta ve ortamda istenmediğini sezmektedir ve bu konuşma sayesinde şüphelendiği hususlarda haklı olduğunu fark eder. Mikrop taşıyıcısı ve hastalık yayıcı olarak etiketlenir; sağlıklı insanların arasında yeri yoktur. Mehmet Tekin'in de belirttiği üzere "Mikrop bölümü, olay örgüsünün, en kritik noktasını teşkil etmektedir. Bu bölüme kadar belli bir seviyede seyreden çocuk-Nüzhet ilişkisi, bu bölümden itibaren çözülmeye başlar" (1999, s. 183). Bu kısma kadar içinde aşkın umudunu taşıyan ve yavaş yavaş iyileşme emareleri gösteren kahraman "Kozmopolitlerin Hücumu" adlı bölümde büyük olasılıkla aşağ1lı duygularının neden olduğu öfke patlamalarıyla Nüzhet ve ailesinden kopar.

Nüzhet'in annesi, kızının doktor Ragıp ile evlenmesi için hayli ısrar eder. Bu talip "[e]tlerinin her parçası aynı pembelikte, sıhhatli[...] başı”, "daima gülmeye alışmış" ağzı gibi özellikleriyle roman kahramanının zıddı olarak tasvir edilir (DHK, s. 61). Anlatıcının yaşına uymayan ciddiyetine karşın Ragıp mizahtan hoşlanır. Anlatıcı, Ragıp'ı sağlıklı bedenine ve sosyal konumuna rağmen küçümser. Ragıp'ın her sözü: "Efendim bu tren yirmi kilometre bile gidemez" benzeri sayılardan, ölçülerden yani bu dünyanın gözle görünen, fiziksel unsurlarından oluşur (DHK, s. 62). Ragıp doktor oluşuyla hayatın pratik tarafında yer alırken anlatıcı hastalığının da etkisiyle derin duygu ve düşüncelerin insanıdır. Ancak yüzeysel bir adam olduğu anlatıcı tarafından sıkça altı çizilen Ragıp'ın, roman kahramanının rakibi hatta kendi deyişiyle "düşmanı" olduğunu unutmamak gerekir. Rakibinin Nüzhet'in isteklerini kavrayabilecek sezgilerden yoksun olduğuna ve Nüzhet'e kendisinin iyi geleceğinden emindir. Ne var ki yaz boyunca Nüzhet'le yaşadığı aşk kısa sürede sonlanır: "Nüzhet, gençle arasındaki ilişkiyi bir oyun, rastgele bir macera olarak gördüğü ve önemsemediği için doktor Ragıb'ın teklifine hayır dememiş ve romandaki trajedinin doğmasına sebep olmuştur" ve anlatıcı aşk acısıyla palazlanan bir hastalık, engelli olma endişesi ve yalnızlığı ile baş başa kalır (Büyükkavas Kuran, 2018, s. 206).

Romanın sonunda okuyucu ana karakter için bir çıkış kapısı olduğunu fark eder. Tüm bu sıkıntılardan kahramanı kurtaracak şey edebiyata sığınmasıdır. Roman boyunca genç kahraman hastane ortamı ile ilgili notlar tutmakta ve etrafta gördüklerini defterine betimlemektedir. "Notlar" isimli son bölümde "[b]ir gün hastanelerde okunmak için bir roman yazsam ve bu notlarımın içine karış- 
tırsam..." (DHK, s. 111) diye not düşerek okuyucuya elinde tuttuğu kitabın bu genç çocuk tarafından yazıldığını ima eder. Böylelikle kahramanın bunca ruhsal ve fiziksel ıstırabın ardından hayat amacını bulduğunu sezeriz. Yazar olacaktır. Bu yolculuk sayesinde hasta psikolojisini öğrenmiş ve yazarlık için elzem olan empati yeteneği gelişmiştir. Bu nedenle de Dokuzuncu Hariciye Koğuşu oluşum romanına (Bildunsroman) uygun olarak biter. “Oluşum romanı gelişim romanının bir çeşitlemesidir. Kahramanın kültürle belirlenmiş bir çevrede öğrenme ve deneyimlerle düşünsel ruhsal yetilerini yüksek karakterli ve uyumlu bir bütün oluşturacak şekilde geliştirerek belli bir kültür idealini gerçekleştirmesinin işler" (Aytaç, 2016, s. 217). Anlatıcı oluşum romanlarının tipik özelliği olan sanatçı olma yolunda adımlar atmıştır. Roman, kurtulan bacak ve yazar olma müjdesi ile olumlu bir şekilde sonlanir.

\section{W. SOMERSET MAUGHAM VE INNSANIN ESARETI (OF HUMAN BONDAGE)}

Peyami Safa gibi oldukça üretken olan, tiyatro oyunundan kısa hikâyeye birçok farklı edebî türde eserler veren, Safa Önal'ın hakkında "[b]izler geçer gideriz; ama Somerset dün vardı, yarına da kalacaktır" dediği W. Somerset Maugham (1874-1965) yirminci yüzyıl İngiliz edebiyatının en saygın edebiyatçllarından biridir (Arpa, 2017, s. 128). Türkçe'ye Tülin Er tarafından İnsanın Esareti (2014) olarak çevrilmiş Of Human Bondage (1915) adlı romanı aynı isimle Hollywood tarafından 1934 ve 1946 yıllarında filme uyarlanmıştır ve yazarın en öne çıkan eseridir. ${ }^{3}$

Philip Carey isimli bir çocuğun yetişkin bir adama dönüşmesini konu edinen eserde genel olarak bir oluşum romanıdır (Bildungsroman). Diğer bir deyişle, roman, yaşamına birtakım şansızlıklarla başlayan ana karakterin çeşitli hatalar yapıp hayatı sorgulayarak yaşam amacını bulduğu bir olgunlaşma serüvenidir. Jale Parla bir Bildungsroman'da "roman kahramanının ne tür seçimlerle karşı karşıya kaldığını ve yaptığı seçimler sonucunda yaşamının nasıl belirlendiğini, neredeyse bir ibret öyküsü gibi" hikâye edildiğini belirtir ve bu anlatı türünün lineer bir zamanı takip ettiğini, dolayısıyla roman başkişisinin "[ç]ocukluk, ilk gençlik, masumiyetin yitişi, kimlik bunalımı ve olgunluk aşamalarından geç[tiğini]" vurgular (2010, s. 260). Ínsanın Esareti romanı bu tanımın tipik bir örneğidir. Philip'in çocukluğundan başlayarak düz bir zamansal çizgide akan anlatıda kahramanın birçok yanlış seçimin bedelini ödedikten sonra kendi hayat yolunu bulduğuna şahit oluruz. Doğuştan yumru ayaklı olmak çocukluğundan itibaren Philip'i esir alır ve uzunca bir süre kimlik bunalımı yaşayan kahramanın karakterinin şekillenmesinde büyük bir rol oynar.

Başkahraman Philip yatılı okul yıllarında sınıf arkadaşlarının eziyetlerine katlanmak zorunda kalır. Örneğin, yatıla okula gönderilince yatakhanenin zorba öğrencileri onu kollarından tutup ayağına dokunur ve Philip'i aşağılarlar. On dokuzuncu yüzyıl İngiliz özel yatılı okul sisteminin (public school) katı disiplini ve otorite odaklı anlayışı nedeniyle özürlü veya hassas çocukları koruyacak bir sistemleri yoktur. Üstelik aşağılanmalara bazen öğretmenler de iştirak eder. Latince çeviri dersinde Philip bir soruya cevap veremeyince öğretmeni Bay Gordon tüm sınıfın içinde en yüksek sesiyle "Mankafa! Mankafa! Yumru ayaklı mankafa!" diye bağırarak roman kahramanını aşağılar (İE, s. 75)4. Dokuzuncu Hariciye Koğuşu'nun kahramanı gibi Philip'in de çocukluk ve ilk gençlik yılları bedensel sorunu nedeniyle büyük 1stıraplar içinde geçer.

Philip Carey'in tek sorunu yumru ayağı değildir. Babasını çok küçük yaşta kaybetmiştir ve annesi ise romanın ilk sayfalarında, o sekiz yaşlarındayken ölür. Varlıklı bir aileden gelmesine rağmen annesinin tutumlu biri olmaması sebebiyle babasından kalan para onu yetişkinliğe kadar ancak idare edebilecektir. Oldukça bencil olan amcası Bay Carey ve onun iyi niyetli ancak mesafeli karısı Bayan Carey, Philip'in bakımını üstlenirler. Bu açıdan baktığımızda da Dokuzuncu Hariciye Koğuşu'nun kahramanı ile aralarında aile yapısı olarak da benzerlik vardır. Her iki karakterde yetim-

\footnotetext{
${ }^{3}$ Bu çalışmada Of Human Bondage adlı İngilizce kaynak metin yerine İnsanın Esareti adlı Türkçe erek metinden alıntılama yapılacaktır.
} 
likleri dolayısıyla yalnız ve korumasız, genç yaşta hayatlarının sorumluluğunu üstlenmiş, olgun, yalnız aynı zamanda bedensel hastalık/engellilik sebebiyle de talihsiz çocuklardır.

Philip de bedensel kusuru nedeniyle aşağılık kompleksi geliştirir ve dolayısıyla karşımıza Peyami Safa'nın kahramanı gibi oldukça hassas ve gururlu ve yer yer sivri dilli bir karakter çıar. Okula başladıktan sonra ayaklarına doğru bakan çocukları hemen fark edip "[a]yaklarını sıranın altına tıkıştırır" ve bu konuyla ilgili herhangi bir bahis onun utançtan yerin dibine girmesine sebep olur (İE, s. 47). Toplum içine girmesiyle diğer çocuklardan farklı olduğunu derinden kavrar. Kusurluluk algısı ve kendi beden imajı, gelişim çağında karakterin özgüvenine büyük bir darbe vurur:

[...] bu zaman zarfında son derece duygusal olup çıkmıştı. Mecbur kalmadıkça asla koşmuyordu, çünkü bunun topallamasını daha görünür kıldığını biliyordu, ayrıca belli bir yürüyüş şekli benimsemişti. Elinden geldiğince, dikkat çekmesin diye çarpık ayağı diğerinin arkasında olacak şekilde sabit duruyor ve sürekli ona bakan var mı diye etrafını izliyordu [...] Çoğu zaman kendi başınaydı. Önceden gevezelik etmeyi sevse de zamanla sessizleşti. Kendisiyle başkaları arasındaki farkı düşünmeye baş ladi (İE, s. 50)

Elbette Philip daha insancıl ve sevgi dolu bir ortamda yetişse kusurluluk şeması geliştirmek yerine bedenini olduğu gibi kabul edebilir ve kendini bir bütün olarak eksik görmeyebilirdi. Romanın ilerleyen kısımlarında Philip cerrahi hastalar bölümünde çalışan bir tıp öğrencisiyken kendisi gibi yumru ayaklı bir çocuğun ebeveynleri, oğullarının durumuyla ilgili yapılabilecek bir şey olup olmadığını öğrenmek için hastaneye başvururlar. Bölümün sorumlu doktoru bu işi yumru ayağından dolayı Philip'e devrettiğinde kahraman artık bir yetişkin olmasına rağmen geliştirdiği kompleks nedeniyle utanıp kızarır ancak hasta çocuğu gördüğünde oldukça şaşırır çünkü bu neşeli ve konuşkan çocuk yumru ayağı dışında Philip'e hiç benzememektedir. Çocuk yumru ayağından dolayı kendini eksik ve değersiz hissetmez: "Sadece görünüşünde bir sorun var, bilirsin işte [...] Bana hiçbir sıkıntı vermiyor" (IE, s. 535). Doktor meslektaşları Philip'in de ayağını görmek istediklerinde yatılı okuldayken yaşadığı travmayı hatırlattığı için terleme gibi istemsiz bedensel tepkiler verir. Philip'in tüm hayatını şekillendiren bedensel engelin aynı dertten mustarip bir başka kişide aynı ruhsal tahribatı yapmaması düşündürücüdür. Roman bu yumru ayaklı çocuğun hikâyesine odaklanmadığ 1 için onun hikâyesini bilemiyoruz. Ne var ki onun iyileşmesi için ellerinden geleni yapmaya hazır ebeveynleri ve muayenede ona destek olan bir babası olduğunu biliyoruz. Philip ve Dokuzuncu Hariciye Koğuşu'nun genç kahramanının onlara yeterince destek olabilecek aileleri yoktur.

Philip küçükken bakımını üstlenen papaz amcası ve yengesi, yaşlı ve çocuksuz insanlar oldukları için bir çocukla nasıl iletişim kurabileceklerini bilmemektedirler. Evin kütüphanesi bu yalnız çocuğa yeni bir dünyanın kapılarını aralar. Bu kütüphane sayesinde güçlü bir okuma alışkanlığı kazanıp gerçek dünyadaki acılarını unutur. Özellikle yatılı okula başladığı süreçte kusurluluk hissinin kahramanı yalnızlaştırmaması olanaksızdır. Philip yaşıtlarıyla arasına bariyer çekip kendini giderek daha çok kitap okumaya verir. Böylece Dokuzuncu Hariciye Koğuşu'nun kahramanına olduğu gibi olumsuz duygu ve deneyimler olumlu bir sonuç doğurmuş olur. Kahraman; felsefe, edebiyat, sanat gibi alanlarda bilgi birikimini arttırarak genç yaşta belli bir entelektüel seviyeye gelmeyi başarır. Bu da bir oluşum romanı olduğunu belirttiğimiz romanda ana karakterin kendi yolunu bulmasında bir anahtar rolü üstlenir:

Geçmişinin uzun ve zorlu yolculuğunu düşününce bunu mutlulukla kabullendi. Hayatı onun için çok zor kılan sakatlığı kabullendi [...] O olmasaydı asla güzelliği böyle hevesle takdir etmez, sanata ve edebiyata tutkuyla bağlanmaz, hayatın çeşitli yönlerine böyle ilgi duymazdı. Sıklıkla uğradığı alay ve küçümsemeler zihninin kendi

${ }^{1}$ İnsanın Esareti ismi ile çevrilen romandan yapılacak alıntılarda romanın adı "IE" şeklinde verilecektir. 
içine dönmesine ve kokularını asla kaybetmeyeceğini hissettiği o çiçeklerin ortaya çıkmasına yol açmıştı. [...] Herkesin bedensel ya da zihinsel bir sakatlı̆̆ı vardı. Tanıdığı tüm insanları düşündü, [...] bedenen sakat ve zihnen yıpranmış bir kafile gördü, bazıları zayıf kalbi veya zayıf ciğerleriyle bedenen hasta, bazıları ise irade zayıflığı ya da içki bağımlılığıyla ruhen hastaydı. O anda hepsi için ilahi bir şefkat hissetti. [...] Tek mantıklı şey, insanın iyi tarafını kabul edip hatalarına sabır göstermekti. Ölmekte olan Tanrının sözleri geçti aklından: Onları bağışla, çünkü ne yap1kların bilmiyorlar (İE, s. 787-788).

Böylelikle roman karakteri fiziksel engel ve yetimlik gibi talihsizliklerin açtığı ruhsal yaralar sebebiyle çıktığ1 olgunlaşma serüvenini tamamlayarak gerçek anlamda yetişkin bir adama dönüşür. Bu anlamda Dokuzuncu Hariciye Koğuşu'nun ana karakteri de Philip'i çağrıştırır. Bedensel kusuru, bir uzvunu kaybetme korkusu ve sahipsizliğinin getirdiği acılar kahramanın psikolojik ve ahlaki gelişimini erken yaşlarda tamamlamasına olanak sağlar.

Safa'nın isimsiz roman kahramanının Nüzhet'e âşık olması gibi Philip de Mildred isimli bir kadını oldukça tutkulu bir şekilde sever. İki karakter de kendi mizaçlarına uygun olmayan kadınlara âşık olmanın sonuçlarına katlanmak zorunda kalır. Philip muhasebe, resim sanatı gibi birçok farklı iş dalını denedikten sonra tıp okumaya karar verdiğinde aslında bu alan hiç ilgisini çekmemekte ve gönülsüzce okula gitmektedir. Tam bu sıralarda bir kafede garsonluk yapan "kalçaları dar, göğsü de oğlan çocuğununki gibi" diyerek çekici olmadığını düşündüğü ve oldukça kaba, hatta görgüsüz denilebilecek Mildred'e saplantılı bir şekilde bağlanır (İE, s. 345). Kendisine göre farklı bir sosyal tabakadan gelen bu genç kadının bayağı tavırlarının Philip de farkındadır. Romanda"görgüsüzlük ve bayağılık hem cinsellik hem de sınıf ayrımı olarak centilmenliğin ve kibarlığın karşısında konumlanur" (Sanders, 2001, s. 192) ${ }^{5}$. İki karakter arasındaki sınıf farkı ve bunun günlük yaşam yansımaları Philip ve Mildred'in ideal bir çift olamayacağının sinyalini belirgin bir şekilde verir. Mildred her ne kadar onunla dışarıda vakit geçirmeyi kabul etse de aslında kadının Philip'e en ufak bir sevgi beslemediği bariz bir şekilde ortadadır. Kahraman Mildred'i hem terslemek ve onun kötü davranışlarının intikamını almak istemekte: "Vay canına, eğer onunla evlenirsem, çektiğim bütün sıkıntıları ona ödeteceğim" hem de kadının yanından ayrılamayacak kadar kendini ona bağımlı hissetmektedir (IE, s. 389). Mildred çalıştı̆̆ı kafede onu görmeye gelen diğer erkeklerle de Philip'in yanında flört etmekten çekinmez ve kısa bir süre sonra Philip'in hassas ve çekingen karakterinin tersine kaba ama özgüvenli bir adam olan Emil Miller ile evleneceğini söyleyip Philip'ten ayrılır. Romanın ilerleyen kısımlarında Mildred o zamanlar İngiltere için de bir tabu olan evlilik dışı bir çocuk dünyaya getirip zaten evli olan sevgilisi onu terk edince Philip'e sığınır. Philip ise kendisine her bakımdan denk ve onu çok seven Norah'tan Mildred için vazgeçer ancak Mildred bu sefer de Philip'i onun en yakın arkadaşlarından Harry Griffiths ile aldatır. Bir yıl kadar sonra Philip, Mildred'e acıyarak tekrar evine alır nihayet ondan onu romantik anlamda sevmekten vazgeçmiştir ama Mildred narsist özellikler göstererek onun tarafından sevilmemeyi bir aşağılanma ve güç kaybı olarak görür:

Sen benim bir kez dahi umrumda olmadın, seni hep aptal yerine koydum [...] senden hep nefret ettim, mesele para olmasaydı bana dokunmana asla izin vermezdim [...] Griffiths'le sana güldük, enayini teki olduğun için güldük sana [...] Ardından yeniden iğrenç hakaretler saydırdı. Her berbat hata için onu suçluyordu [...] Ardından Philip'i gerçekten yaraladığını bildiği tek şey olan sakatlığına küfrü bastı. [...] Bir tokat gibi onu Philip'e patlatt1. "Topal!" (IE, s. 625).

Görüleceği üzere Philip'in aşkı tek taraflıdır ve Mildred'i her kabul edişinde kadın onun canını yakarak karşılık verir. Buna rağmen Philip'in Mildred'ten vazgeçmesi yıllarını alır. Mildred her ne kadar Nüzhet gibi üst sosyal tabakalardan gelmese de duyarsızlık ve yüzeysellik bakımından

\footnotetext{
${ }^{5}$ Alıntı, kaynak metinde şu şekilde geçer: 'gentility is positioned against it sopposite, vulgarity, viewed in sexuality and classed terms'.
} 
Nüzhet'in bir benzeridir. Elbette İnsanın Esareti oldukça ayrıntılı ve uzun bir roman olduğu için Mildred hakkında Nüzhet'e göre çok daha fazla bilgimiz var ama burada dikkat çeken unsur roman kahramanlarının anlatıcılar tarafından benzer şekilde duygusuz ve derinliksiz olarak tasvir edilen kadınlara ilgi duymasıdır. İki kahramanın da çoğunlukla kronik hastalık veya engellilik sebebiyle gelişen aşağılık duygusu sonucunda kendilerini değersiz hissetmeleri ve bu nedenle değersizlik algılarını tasdik edecek ve zaten en başında birlikte olmalarının imkânsız göründüğü kadınlara arzu duymaları pek de şaşırtıcı değildir.

Bu noktada Philip'in bedensel sorunundan dolayı kadınlar tarafından istenmediğini düşünmek yanlış olacaktır. Roman boyunca Bayan Wilkinson, Fanny Price, Norah gibi kadınlar ona büyük bir aşkla bağlanmış ama Philip bu kadınlara karşı derin duygular besleyememiştir. Romanın sonlarında Philip, Sally isimli alt sınıflardan başka bir genç kızla evlenmek istediğinde kız yüzünde herhangi bir duygu belirtisi olmadan neredeyse Mildred konuşuyormuşçasına bu teklifi gönülsüzce kabul ediyor gibidir: "Öyle istiyorsan, [...] kendi evim olsun isterim, hem yuva kurma vaktim geldi, [...] evlenebileceğim başka kimse yok" (İE, s. 791-792). Buradan anlaşılacağı üzere roman kahramanı Mildred ile olan zararlı ilişkisinden yeterince ders çıkartamamış gibidir. Romanın son sayfası okuyucuya İnsanın Esareti başlığına uygun olarak Philip'in kendini tutkuyla sevmeyen kadınlara olan esaretinden kurtulamayacağının işaretlerini verir.

Birçok benzerlikleri olsa da Philip'in Dokuzuncu Hariciye Koğuşu'nun çocuk kahramanından farkı da tam olarak burada yatar. Philip de küçük yaşlardan beri sanat/entelektüellik ile pratiklik dikotomisi arasında gider gelir ancak tercihini sanatçı doğasına rağmen pratiklikten yana kullanır. Bu tercihin ilk örneğini ressam olmak için Paris'te resim eğitimi aldığı sırada görüşlerine güvendiği profesör Mösyö Foniet ona belli bir el becerisi olsa da "orta karar bir ressamdan başka bir şey olamazsın asla dedikten sonra bu tutkusundan vazgeçtiğinde görüyoruz (İE, s. 320). Sanatçı çevresinden Fanny Price, Hayward, Miguel gibi tanıdıkları sanat konusunda oldukça tutkulu ama başarısız insanlardır. Philip başarısız ve sefil bir hayat sürmek yerine tıp eğitimi almaya karar vererek hayatı yani pratik yaşamı seçer. Pratiklik kutbuna yakın ikinci büyük kararı ise doktor olduktan sonra "bir eşe, bir eve ve sevgiye duyduğu arzu" sebebiyle gemilerle dünyayı dolaşma isteğinden vazgeçmesidir (İE, s. 790). Burada ana karakterin orta sınıfın konformizmiyle uzlaştığını ama bunu bir fedakârlıktan ya da zorunluluktan yapmadığını aksine kendi iç dünyasını daha iyi anlayabildiği için böyle bir tercihte bulunduğunu düşünüyoruz. Ancak bu Philip'in sanat ve düşünce dünyasına tamamen sırtını döndüğü anlamına gelmez. Chronshaw isimli şair Philip'e hayatın anlamının İran halılarının desenlerinde saklı olduğunu söyler. Romanın sonunda Philip İran halısı metaforuyla hayatın anlamını bulur. Buna göre her bir birey, bir sanatçı gibi "hayatına, yaptıklarına, hislerine, düşüncelerine dair çeşitlilik arz eden olaylardan düzenli, detaylı, karmaşık ya da güzel bir desen yaratabilir (İE, s. 684). Diğer bir deyişle, hayatı yaşama biçimimizin kendisi bir sanattır ve her insan bir sanatçı gibi hayatını dokur. Philip'e göre; "[b]ir insanın içinde doğduğu en bariz, mükemmel ve güzel desen büyüyüp erkek olmak, evlenmek, çocuk yapmak, ekmeği için çalışmak ve ölmekti; ama karmaşık ve harika olan başkaları da vardı ve bunlara mutluluk giremez başarı dâhil olamazdı" (ibid). Görüldügü üzere Philip pratik hayatın kendisinin sanat olarak tanımlanabileceğini düşünür. Büyük olasılıkla çocukluğunda bedensel deformasyonundan dolayı toplumun ona hissettirdiği farklılığı ve amcasının evindeki kütüphane sayesinde edindiği yoğun okuma alışkanlığı Philip'te küçük yaşlarından itibaren toplumun genelinden farklı olma isteğine yol açmıştır. Romanın sonunda kahraman arayışını tamamlamış ve bir anlamda başa dönmüştür çünkü onca maceradan ve acıdan sonra sıradan hayatın güzelliğini fark etmiştir fakat bu başa dönüş kesinlikle bir başarısızlık veya boşa harcanmış bir zaman değildir. Tersine bir oluşum romanından (Bildungsroman) beklendiği üzere Philip kendi kimliğini bulmuş, düşünsel ve manevi eğitimini tamamlayıp olgunlaşmıştır. 


\section{SONUÇ}

Bu çalışmada öncelikle Peyami Safa'nın Dokuzuncu Hariciye Koğuşu'nun isimsiz genç kahramanı ele alınmış, sonrasında ise Somerset Maugham'ın Insanın Esareti (Of Human Bondage) adlı eserinin Philip Carey adlı ana karakteri karşılaştırmalı olarak incelenmiştir. Türk ve İngiliz edebiyatının iki güçlü edebiyat örneğini bedensel sorunlar ekseninde bir araya getirmiş olan bu çalışma, farklı kültürlerde yetişseler de benzer koşul ve arka planlardan gelen iki roman karakteri arasındaki koşutlukları görünür kılmıştır. Doğuştan ya da çok küçük yaşlarda ortaya çıktığı için çocukluk döneminde karakterlerin kişiliğini şekillendiren bedensel "kusur" veya kronik hastalıklar bu karakterleri hassas, çekingen ve alıngan yapmış ve hatta aşağılık duygusu geliştirmelerine neden olmuştur. Buna ilaveten genç yaşta yaşanan ebeveyn kayıpları kahramanlar için hayatı daha da zorlaştırmış ve aynı zamanda küçük yaşta yetim kalma ile ilintili olduğunu ileri sürebileceğimiz yoksulluk mefhumu her iki romanın atmosferine iyice sinmiştir. her iki metin de özellikle bedensel rahatsızlık ve "kusur" bağlamında insan doğasına ilişkin okuyucunun derinlikli çözümlemeler yapmasına olanak verir. Çocukluk ve gençlik yıllarındaki ruhsal gelişime ve ahlaksal olgunlaşmaya odaklanan bu eserler oluşum romanı (Bildungsroman) türüne örnek olmaları hususunda da paralellik gösterir. Bedensel sorunların güçlendirdiği sanatçı doğaları ve yine büyük ihtimalle bu sorunlar sebebiyle kendilerini gönülden sevemeyecek kadınlara çekim duymalarından kaynaklanan aşk acıları ile derinleşen gelişim serüvenlerinin sonunda her iki karakter de hayat amaçlarını ve toplumdaki yerlerini bulduklarının güçlü işaretlerini verirler. Dokuzuncu Hariciye Koğuşu'nun ana karakteri düşünce ve sanat dünyasında yazar olarak var olacak, İnsanın Esareti (Of Human Bondage)'nin Philip Carey'si ise sanat yerine pratik hayatı seçecek ama onu bir sanat olarak yorumlayacaktır.

\section{KAYNAKÇA}

Arpa, Yasemin (2017). "Ne Kadar Gamlı Bu Akşam Vakti": Safa Önal Kitabı. İstanbul: Profil Kitap.

Aytaç, Gürsel (2016). Karşılaştırmalı Edebiyat Bilimi. Ankara: Doğu Batı Yayınları.

Ayvazoğlu, Beşir (2017). Peyami: Hayatı, Sanatı, Felsefesi, Dramı. İstanbul: Kapı Yayınları.

Büyükkavas Kuran, Şeyma (2018). Peyami Safa'nın İnsanları. İstanbul: Ötüken Neşriyat.

Gürbilek, Nurdan. (2010). Kör Ayna, Kayıp Şark: Edebiyat ve Endişe. İstanbul: Metis Yayınları.

Margolis, Howard and Arthur Shapiro (1987). Countering Negative Images of Disability in Classical Literature. The English Journal, 76(3), 18-22. doi:10.2307/818530

Maugham, W. Somerset (2017). İnsanın Esareti. çev. Tülin Er. İstanbul: Türkiye İş Bankası Kültür Yayınları.

Parla, Jale (2010). Don Kişot'tan, Bugüne Roman. İstanbul: İletişim Yayınları.

Safa, Peyami (1968). Dokuzuncu Hariciye Koğuşu. İstanbul: Ötüken Neşriyat.

Sanders, Lise Sahpiro. (2001). 'The Failures of the Romance: Boredom, Class, and Desire in George Gissing's The Odd Women and W. Somerset Maugham's Of Human Bondage'. Modern Fiction Studies, 47 (1), 190-228. Retrieved January 10, 2021, from http:/ /www.jstor.org/sta$\underline{\text { ble/26286029 }}$

Sonntag, Susan (1978). Illness as Metaphor. New York: Farrar, Straus and Giroux.

Tekin, Mehmet (1999). Romancı Yönüyle Peyami Safa: Romanların Teorik ve Teknik Temelleri. İstanbul: Ötüken Neşriyat. 


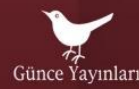

Prof. Dr. Önder Göçgün

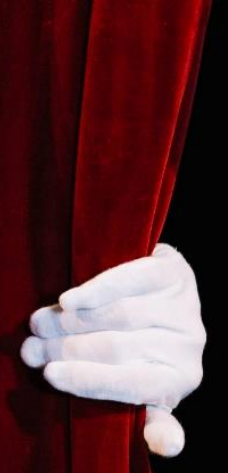

TIYYATRO DENEN HAYAT

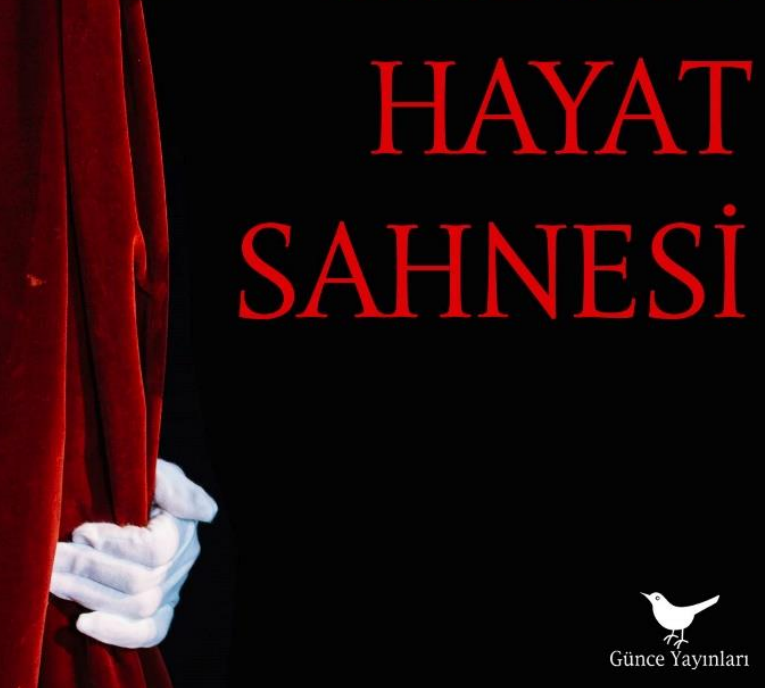

MUIIARREM DAYANC OKTAY YIVLI MACI'I BALIK MAIIMU'I BABACAN SLVIM SLERMEI
YASFMIN MUMCU BLDI் KOÇАKOĞLU NILÜLLLR ILLHAN MAKSUT YIĞITBAS SLL $\triangle M I I L \Lambda N$

\section{EDEBIYATINDA

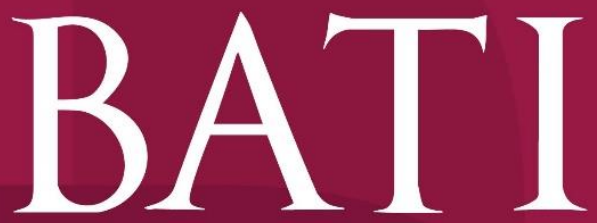 \\ EDEBIYATINDA
AKIMLAR \\ $\underset{\substack{\text { EDEBIYATINDA } \\ \text { AKIMLAR }}}{\mathrm{B} A T \mathrm{~T}}$}

editör

OKTAY YIVLI

HATICE FIRAT

YASEMIN MUMCU

OKTAY YIVLI

OĞUZHAN KARABURGU

BERNA AKYÜZ SIZGEN

NILÜFER ILHAN
ÜMMÜHAN TOPÇU

SEFA YÜCE

HANIFI ASLAN

METIN AKYÜZ

MEHMET SÜMER
YAKUP ÖZTÜRK
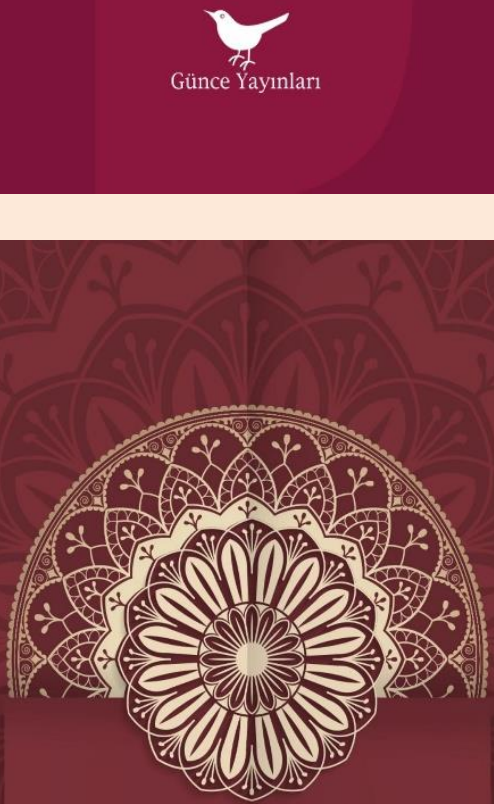

PROF. DR. ÖNDER GÖÇGÜN

$$
\begin{gathered}
\text { Türk } \\
\text { Tasavvuf } \\
\text { Siini }
\end{gathered}
$$

AÇIKLAMALI VE YORUMLU ÖRNEKLERLE 